\title{
Editorial \\ Celebrating 120 Years of Butantan Institute Contributions for Toxinology
}

Ana M. Moura-da-Silva

check for

updates

Citation: Moura-da-Silva, A.M. Celebrating 120 Years of Butantan Institute Contributions for

Toxinology. Toxins 2022, 14, 76. https://doi.org/10.3390/ toxins14020076

Received: 11 January 2022 Accepted: 19 January 2022 Published: 21 January 2022

Publisher's Note: MDPI stays neutral with regard to jurisdictional claims in published maps and institutional affiliations.

Copyright: (c) 2022 by the author. Licensee MDPI, Basel, Switzerland. This article is an open access article distributed under the terms and conditions of the Creative Commons Attribution (CC BY) license (https:// creativecommons.org/licenses/by/ $4.0 /)$.
Laboratório de Imunopatologia, Instituto Butantan, Av. Vital Brasil, 1500, São Paulo 05503-900, SP, Brazil ana.moura@butantan.gov.br

A hundred and twenty years ago, the Butantan Institute was founded by the Brazilian physician and scientist Vital Brazil, combining, in the same institution, medical research, and the transfer of results to society in the form of health products. Its foundation was a reaction to the outbreak of bubonic plague in the city of Santos, São Paulo State of Brazil, but the Institution soon also showed its specialization in the study of venomous animals, their venoms, and the production of antivenoms. More than a century after its foundation, the Institute maintains its tradition and initial mission regarding important contributions for collective health. Today, Butantan is an outstanding biomedical research center, which integrates basic research, technological development, the production of immunobiological, and scientific divulgation, seeking the permanent updating and integration of its resources. Butantan is internationally known for its research on venomous animals, and houses one of the largest collections of snakes in the world. Butantan scientists have published countless studies on the characterization of the composition of venoms, the mechanisms of action of their toxins, and the use of toxins as lead molecules for the development of new drugs. The Butantan Institute also operates the "Hospital Vital Brazil", which is specialized in accidents involving venomous animals. The dissemination of scientific knowledge occurs at different levels and media; the institution is a pioneer in the training of graduate students in the field of Toxinology for MSc and PhD degrees.

This Special Issue of Toxins celebrates the 120th anniversary of the Butantan Institute, in recognition of their contribution to international Toxinology, highlighting the current production by house scientists and collaborators from other institutions. We selected 19 original articles and 4 reviews approaching several points of Toxinology. The venom of snakes was approached in different aspects as the structural and functional variability in the composition of venoms from individual snakes [1], the mechanisms of action of whole venoms [2,3], the mechanisms of action of individual components as crotoxin [4], phospholipases A2 [5], metalloproteinases [6-8], and the oral immunity induced by whole venoms and their components [9]. Venoms from other animals are also reported; the venoms of centipedes [10], scorpions [11,12], fishes [13,14], and caterpillars [15], including microbial toxins [16]. The great potential for molecules derived from animal venoms as drug leads was also reviewed [17], and the antimicrobial [18], anticoagulant [19,20], and analgesic $[21,22]$ effects have been highlighted in original studies reported here.

In conclusion, this is a small recognition of the institute's contribution to the field of Toxinology that demonstrates its continued and relevant role in this field. I hope you enjoy reading this, and congratulations to the Butantan Institute, scientists, and collaborators, on their 120th anniversary.

Funding: The publication fees of this issue were sponsored by Fundação Butantan.

Conflicts of Interest: The authors declare no conflict of interest. 


\section{References}

1. Sousa, L.F.; Holding, M.L.; Del-Rei, T.H.M.; Rocha, M.M.T.; Mourão, R.H.V.; Chalkidis, H.M.; Prezoto, B.; Gibbs, H.L.; Moura-daSilva, A.M. Individual Variability in Bothrops atrox Snakes Collected from Different Habitats in the Brazilian Amazon: New Findings on Venom Composition and Functionality. Toxins 2021, 13, 814. [CrossRef]

2. Megale, Â.; Magnoli, F.C.; Guidolin, F.R.; Godoi, K.S.; Portaro, F.C.V.; Dias-da-Silva, W.; Snake, V. Kn-Ba, a Snake Venom Serine Protease, Induce the Production of Inflammatory Mediators in THP-1 Macrophages. Toxins 2021, 13, 906. [CrossRef]

3. Kisaki, C.Y.; Arcos, S.S.S.; Montoni, F.; da Silva Santos, W.; Calacina, H.M.; Lima, I.F.; Ca-jado-Carvalho, D.; Ferro, E.S.; Nishiyama, M.Y., Jr.; Iwai, L.K. Bothrops Jararaca Snake Venom Modulates Key Cancer-Related Proteins in Breast Tumor Cell Lines. Toxins 2021, 13, 519. [CrossRef] [PubMed]

4. Kato, E.E.; Sampaio, S.C. Crotoxin Modulates Events Involved in Epithelial-Mesenchymal Transition in 3D Spheroid Model. Toxins 2021, 13, 830. [CrossRef] [PubMed]

5. Moreira, V.; Leiguez, E.; Janovits, P.M.; Maia-Marques, R.; Fernandes, C.M.; Teixeira, C. In-flammatory Effects of Bothrops Phospholipases A2: Mechanisms Involved in Biosynthesis of Lipid Mediators and Lipid Accumulation. Toxins 2021, 13, 868. [CrossRef] [PubMed]

6. Zychar, B.C.; Clissa, P.B.; Carvalho, E.; Alves, A.S.; Baldo, C.; Faquim-Mauro, E.L.; Gon-çalves, L.R.C. Modulation of Adhesion Molecules Expression by Different Metalloproteases Isolated from Bothrops snakes. Toxins 2021, 13, 803. [CrossRef] [PubMed]

7. Gimenes, S.N.C.; Sachett, J.A.G.; Colombini, M.; Freitas-de-Sousa, L.A.; Ibiapina, H.N.S.; Costa, A.G.; Santana, M.F.; Park, J.J.; Sherman, N.E.; Ferreira, L.C.L.; et al. Observation of Bothrops atrox Snake Envenoming Blister Formation from Five Patients: Pathophysiological Insights. Toxins 2021, 13, 800. [CrossRef] [PubMed]

8. Bertholim, L.; Chaves, A.F.A.; Oliveira, A.K.; Menezes, M.C.; Asega, A.F.; Tashima, A.K.; Zelanis, A.; Serrano, S.M.T. Systemic Effects of Hemorrhagic Snake Venom Metalloproteinases: Untargeted Peptidomics to Explore the Pathodegradome of Plasma Proteins. Toxins 2021, 13, 764. [CrossRef]

9. Tsuruta, L.R.; Moro, A.M.; Tambourgi, D.V.; Sant'Anna, O.A. Oral Tolerance Induction by Bothrops jararaca Venom in a Murine Model and Cross-Reactivity with Toxins of Other Snake Venoms. Toxins 2021, 13, 865. [CrossRef]

10. De Lucca Caetano, L.H.; Nishiyama, M.Y., Jr.; de Carvalho Lins Fernandes Távora, B.; de Oliveira, U.C.; de Loiola Meirelles Junqueira-de-Azevedo, I.; Faquim-Mauro, E.L.; Magalhães, G.S. Recombinant Production and Characterization of a New Toxin from Cryptops iheringi Centipede Venom Revealed by Proteome and Transcriptome Analysis. Toxins 2021, 13, 858. [CrossRef]

11. Barbosa, M.O.R.; de Paulo, M.E.F.D.; Nencioni, A.L.A. Scorpion Envenomation of Lactating Rats Decreases the Seizure Threshold in Offspring. Toxins 2021, 13, 853. [CrossRef] [PubMed]

12. Duzzi, B.; Silva, C.C.F.; Kodama, R.T.; Cajado-Carvalho, D.; Squaiella-Baptistão, C.C.; Portaro, F.C.V. New Insights into the Hypotensins from Tityus serrulatus Venom: Pro-Inflammatory and Vasopeptidases Modulation Activities. Toxins 2021, 13, 846. [CrossRef] [PubMed]

13. Lopes-Ferreira, M.; Sosa-Rosales, I.; Silva-Junior, P.I.; Conceicao, K.; Maleski, A.L.A.; Balan-Lima, L.; Disner, G.R.; Lima, C. Molecular Characterization and Functional Analysis of the Nattectin-like Toxin from the Venomous Fish Thalassophryne maculosa. Toxins 2022, 14, 2. [CrossRef]

14. Campos, F.V.; Fiorotti, H.B.; Coitinho, J.B.; Figueiredo, S.G. Fish Cytolysins in All Their Complexity. Toxins 2021, 13 , 877. [CrossRef]

15. Alvarez-Flores, M.P.; Gomes, R.N.; Trevisan-Silva, D.; Oliveira, D.S.; Batista, I.F.C.; Buri, M.V.; Alvarez, A.M.; DeOcesano-Pereira, C.; de Souza, M.M.; Chudzinski-Tavassi, A.M. Lonomia obliqua: Envenoming and Innovative Research. Toxins 2021, 13, 832. [CrossRef]

16. Luz, D.; Gómez, F.D.; Ferreira, R.L.; Melo, B.S.; Guth, B.E.C.; Quintilio, W.; Moro, A.M.; Presta, A.; Sacerdoti, F.; Ibarra, C.; et al. The Deleterious Effects of Shiga Toxin Type 2 Are Neu-tralized In Vitro by FabF8:Stx2 Recombinant Monoclonal Antibody. Toxins 2021, 13, 825. [CrossRef]

17. Coelho, G.R.; da Silva, D.L.; Beraldo-Neto, E.; Vigerelli, H.; de Oliveira, L.A.; Sciani, J.M.; Pimenta, D.C. Neglected Venomous Animals and Toxins: Underrated Biotechnological Tools in Drug Development. Toxins 2021, 13, 851. [CrossRef]

18. Oguiura, N.; Corrêa, P.G.; Rosmino, I.L.; Souza, A.L.; Pasqualoto, K.F.M. Antimicrobial Ac-tivity of Snake $\beta$-Defensins and Derived Peptides. Toxins 2022, 14, 1. [CrossRef]

19. Aounallah, H.; Fessel, M.R.; Goldfeder, M.B.; Carvalho, E.; Bensaoud, C.; Chud-zinski-Tavassi, A.M.; Bouattour, A.; M'ghirbi, Y.; Faria, F. rDromaserpin: A Novel Anti-Hemostatic Serpin, from the Salivary Glands of the Hard Tick Hyalomma dromedarii. Toxins 2021, 13, 913. [CrossRef]

20. Linhares, D.D.C.; Faria, F.; Kodama, R.T.; Amorim, A.M.X.P.; Portaro, F.C.V.; Trevisan-Silva, D.; Ferraz, K.F.; Chudzinski-Tavassi, A.M. Novel Cysteine Protease Inhibitor Derived from the Haementeria vizottoi Leech: Recombinant Expression, Purification, and Characterization. Toxins 2021, 13, 857. [CrossRef]

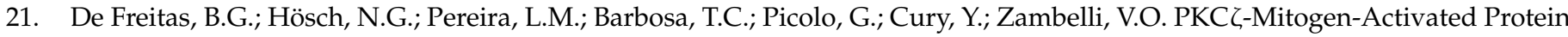
Kinase Signaling Mediates Crotalphine-Induced Antinociception. Toxins 2021, 13, 912. [CrossRef] [PubMed]

22. Giardini, A.C.; Evangelista, B.G.; Sant'Anna, M.B.; Martins, B.B.; Lancellotti, C.L.P.; Ciena, A.P.; Chacur, M.; Pagano, R.L.; Ribeiro, O.G.; Zambelli, V.O.; et al. Crotalphine Attenuates Pain and Neuroinflammation Induced by Experimental Autoimmune Encephalomyelitis in Mice. Toxins 2021, 13, 827. [CrossRef] [PubMed] 